\title{
Religião, política e ordem social nos Atos Apócrifos dos Apóstolos
}

\author{
Religion, politics and social order in the Apocryphal Acts of the \\ Apostles
}

\author{
José Adriano Filho*
}

RESUMO

Os Atos Apócrifos dos Apóstolos recontam a tradição dos apóstolos e suas façanhas públicas. Os apóstolos são apresentados em constante conflito com o mundo à sua volta. Eles demonstram o poder do único Deus verdadeiro por meio de milagres, ascetismo e martírio. O cristianismo que eles representam contrasta com as crenças e poder do mundo greco-romano. Esta instância antissocial é reforçada pela mensagem de castidade anunciada pelos apóstolos, a qual interrompe o casamento, e nos conflitos com as autoridades civis e religiosas. Eles têm preocupações apologéticas, missionárias e de edificação, mas rejeitam os ideais culturais e sociais tradicionais em favor de novos ideais. Os Atos Apócrifos também refletem a rede do patronato social e político contemporâneo do Império romano. Eles redefinem o patronato de uma perspectiva cristã e desafiam o sistema estabelecido ao apresentar a Cristo como o verdadeiro patrono, superior aos patronos humanos, incluindo o imperador. A tentativa de reformular as pressuposições estabelecidas é uma característica que define a identidade cristã representada nesta literatura.

Palavras-chave: Atos Apócrifos dos Apóstolos; Ascetismo; Patronato; Cristianismo; Império Romano.

\section{ABSTRACT}

The Apocryphal Acts of the Apostles recounts the tradition of the apostles and their public deeds. They are presented in conflict with the world around them, and they demonstrated the power of the Only One God through miracles, asceticism and martyrdom, and Christianity they represent contrasts with the beliefs and power of the Greek-Roman world. This antisocial instance is reinforced by the chastity message preached by the apostles which leads to the breakup of the marriage bond, and in the conflicts

\footnotetext{
* José Adriano filho, doutor em Ciências da Religião (UMESP) e em Teoria e História Literária (UNICAMP), é professor da Faculdade Unida de Vitória - ES.
} 
between the apostles and the civil and religious authorities. They also have apologetic, missionary, and edification concerns, but they reject the traditional cultural and social ideals in favor of new ones. The Apocryphal Acts also reflect the network of social and political patronage of the then-current Roman Empire; and redefine it from a Christian viewpoint. They present Christ as the true patron, the one above human patrons, including the emperor. The attempt to reformulate the established assumptions is a defining characteristic of the Christian identity represented in this kind of literature.

Keyword: Apocryphal Acts of the Apostles; Ascetism; Patronage; Christianity; Roman Empire.

Os Atos Apócrifos dos Apóstolos constituem um gênero literário no qual a imaginação narrativa do cristianismo primitivo amplamente se expressa. Eles assemelham-se aos romances grecoromanos e judaicos antigos, empregam diversos motivos e formas literárias, apresentam afinidades com os romances ideais, dos romances históricos e adaptam características dos romances do herói nacional e das novelas biográficas (BAUCKHAM, 2000, p. 799-806). Eles refletem o contexto teológico da sua época através do apóstolo como portador de uma tradição do cristianismo. Os apóstolos são os intermediários entre o Deus transcendente e o mundo físico. Suas palavras e ações revelam a efusão do sobrenatural na história e o seu papel na revelação do poder de Deus e do caminho da salvação ocorre neste mundo dos sentidos, corrupto, transitório, enganoso e que está sob o domínio do mal. Através dos apóstolos, Deus oferece a salvação à humanidade, a qual acontece por meio da aceitação da revelação do poder divino, sabedoria e mistério (RHEE, 2005, p. 86-87).

Os Atos Apócrifos dos Apóstolos apresentam também diversos milagres realizados pelos apóstolos como prova do monoteísmo e da superioridade da fé cristã. No mundo popular grecoromano, a ideia de divindade estava ligada à manifestação do poder divino e a obsessão com tal poder expressava-se no fascínio com o sobrenatural e aqueles que os realizavam ou reivindicavam realizá-los. As religiões exploravam este mercado saturado de milagres e mágica e competiam por fidelidade popular, demonstrando os seus milagres e classificando os milagres rivais como mágica. A presença do extraordinário como essência do poder era o ponto de contato com o divino e uma poderosa forma de persuasão, sendo que os milagres realizados pelos deuses e a propaganda literária a eles associada eram utilizados como meio de atrair convertidos para as novas religiões. Nesse sentido, o valor religioso dos milagres apresentados nos Atos apócrifos indica a superioridade do Deus cristão, demonstrada no seu poder sobrenatural sobre os deuses pagãos, demônios, doenças e morte, provocando a conversão de indivíduos, famílias e pessoas (RHEE, 2005, p. 71-79).

Os Atos Apócrifos dos Apóstolos são obras históricas não em termos de precisão factual, mas porque utilizam criativamente a história ao recontar a tradição dos apóstolos e suas façanhas públicas. Eles focalizam a carreira missionária do apóstolo com um objetivo apologético e propagandístico em favor de um grupo particular ou ethos religioso, recontam da história do passado e projetam-na no milieu teológico e social contemporâneo, fornecendo uma perspectiva 
histórica da sociedade greco-romana, do cristianismo contemporâneo e do conflito entre eles. Os Atos Apócrifos refletem também a rede do patronato social e político contemporâneo do Império Romano. Eles redefinem o patronato de uma perspectiva cristã e desafiam o sistema existente estabelecido ao apresentar a Cristo como o verdadeiro patrono, superior aos patronos humanos, incluindo o imperador (RHEE, 2005, p. 176-179).

\section{Os apóstolos e as autoridades políticas}

Os confrontos que os Atos Apócrifos apresentam estão representados nos conflitos que envolvem os apóstolos e as autoridades políticas, como governadores, rei e imperador. Estes conflitos envolvem o tema da rivalidade masculina e o rompimento do casamento, pois a mensagem ascética ${ }^{1}$ anunciada pelos apóstolos provoca a ruptura do casamento e dos costumes sociais, acarretando a perseguição da mulher convertida da parte do seu marido e/ou noivo. Em Atos de Paulo e Tecla, Demas e Hermógenes aconselham Tamiris, que foi rejeitado por Tecla, sua noiva, depois que ela ouviu a pregação de Paulo, a levá-lo diante do governador e denunciá-lo como "cristão":

Tamiris, pondo-se de pé diante do Tribunal, disse em altos brados: 'Ó proconsul, este homem, a quem não sabemos de onde é, faz as virgens

\footnotetext{
${ }^{1}$ No mundo greco-romano, a atitude e comportamento ascético eram comuns às diversas escolas filosóficas e seitas religiosas. Ascetismo deriva do termo askesis, que denota "treino militar" ou "disciplina", significando várias formas de auto-renúncia das necessidades físicas e sociais, como alimento, riqueza, conforto e sexo, por razões filosóficas ou religiosas. Os ideais ascéticos do médio platonismo, dos estóicos e dos cínicos influenciaram o cristianismo nascente, que seletivamente adotou e incorporou os seus ideais. O dualismo platônico defende um corpo mutável e mortal ao lado da alma imutável e imortal, gerando o desprezo do corpo como oposto à alma pura, espiritual. Os estóicos aceitavam a realidade da existência corporal, mas não davam importância ao corpo na busca da filosofia. Os platônicos e os estóicos enfatizavam a supremacia e prioridade da razão sobre o corpo, usando o poder da mente para subjugá-lo e controlá-lo. Os estóicos, cujos ensinos éticos foram incorporados no médio platonismo e forneceram espinha dorsal moral e ideológico do Império, falam sobre o domínio dos desejos e atitudes (enkrateia) ao apresentar a vida interior em conformidade com a razão, isto é, acordo com o logos, e aceitavam as normas sociais e deveres na quietude de uma vida de acordo com a natureza. Enfatizavam o afastamento das paixões e desejos interiores (apatheia) e a separação da mente dos afazeres e circunstâncias externas através da disciplina da mente (autarkéia). Os cínicos fundamentavam a virtude no individualismo e liberdade frente ao modo convencional de existência, comportavam-se de forma ascética radical e limitavam as exigências da vida para elementos essenciais básicos; acentuavam a independência radical e rejeitavam as estruturas sociais tradicionais, necessidades e valores. Independentemente dos vários graus de auto-negação e perspectivas negativas do mundo, suas perspectivas e comportamentos ascéticos lidam com a tensão "estar no mundo, mas não do mundo". O paradigma general do ascetismo cristão envolve certo dualismo, principalmente o dualismo deste mundo e do outro mundo, motivado pelo ímpeto apocalíptico e escatológico e também pelo dualismo platônico espírito-matéria. O mundo dos sentidos e a existência corporal que envolve sofrimento, dor e perseguições não pode ser comparado com o mundo por vir, quando o próprio Deus galardoará o bem e punirá o mal. Por essa razão, os cristãos viviam na expectativa do julgamento final, da salvação eterna e ressurreição, e perseveravam com coragem, renunciavam o prazer temporal, o conforto e o desejo com certo desdém, pois haviam de prestar contas ao Justo Juiz da vida na terra. Neste paradigma, o exemplo do ideal ascético envolve o desprezo para com a morte e o prazer pelo martírio. Os cristãos eram conhecidos tanto pelo seu desprezo para com a morte quanto pela prontidão para com ela. Cf. RHEE, Helen. Early Christian Literature, p. 108.
} 
avessas ao casamento, que ele lhe diga o porquê de estar ensinando essas coisas!' Demas e Hermógenes disseram a Tamiris: 'Diga que ele é um cristão, e assim você o arruinará'. O proconsul expôs sua compreensão, chamou Paulo, e disse: 'Quem é você, e o que você ensina?' Pois não são pequenas as acusações contra você (Atos de Paulo e Tecla 16).

Paulo, então, foi preso pelo governador, açoitado e lançado para fora da cidade, e Tecla, a nova convertida, condenada à morte por "quebrar a lei dos moradores de Icônio".

O governador ordenou que Paulo fosse levado ao Tribunal. Tecla, por sua vez, rolava pelo chão no lugar onde Paulo, sentado, a instruía na prisão. Por isso, o governador mandou que ela também fosse conduzida ao tribunal. $\mathrm{E}$ Tecla foi exultante de alegria. Quando Paulo foi apresentado novamente, a multidão gritava: 'Ele é um bruxo! Levem-no embora!' Após convocar uma assembleia, o governador intimou Tecla, e disse-lhe: "Por que você não se casa com Tamiris conforme a lei de Icônio?" Ela, porém, permanecia de pé com os olhos fixos em Paulo. E como Tecla não respondeu, Teoclia, sua mãe, gritou, dizendo: 'Queimem o sem lei! Queimem no meio do teatro aquela que não quer se casar, para que todas as mulheres que este homem instruiu temam'. O governador sentiu-se muito comovido e, depois de açoitar Paulo, o expulsou da cidade e condenou Tecla à fogueira. Imediatamente 0 governador foi até o teatro, e toda a multidão foi ver o espetáculo (Atos de Paulo e Tecla 20-21).

Tecla foi resgatada do martírio miraculosamente e, logo depois, conduzida à presença de Alexandre, o governador, em Antioquia, apenas para ser condenada às bestas selvagens. Ela foi acusada de "sacrilégio", pois desonrara Alexandre ao recusar publicamente seu ataque sexual e derrubar sua coroa com a insígnia imperial:

Paulo enviou Onesíforo e os de sua casa para Icônio; então, tendo Tecla como companheira, partiu para Antioquia. Ao entrarem na cidade, certo homem chamado Alexandre, o Sírio, ao ver Tecla apaixonou-se por ela, e tentou cair nas graças de Paulo oferecendo-lhe brindes e presentes. [...] Alexandre, um homem muito forte, a agarrou na rua. Tecla, não suportando tal coisa, ficou à procura de Paulo. Ela gritou amargamente, dizendo: 'Não 
force uma estrangeira! Não me maltrate, pois sou uma serva de Deus. Sou uma cidadã de Icônio muito importante, e porque eu não quis me casar com Tamiris, fui expulsa da cidade'. Atacando Alexandre, ela rasgou sua túnica e arrancou sua coroa, e, assim, ela fez dele motivo de riso [...] (Atos de Paulo e Tecla 26).

Alexandre não podia tolerar tal insulto e, então, conduziu Tecla ao proconsul, que imediatamente condenou-a a ser atirada aos animais selvagens:

Quando os animais selvagens eram conduzidos em procissão, Tecla foi amarrada a uma leoa feroz, e a rainha Trifena a acompanhava. Mas a leoa, com Tecla assentada sobre ela, lambia seus pés, e toda a multidão ficou surpreendida. A acusação em seu letreiro era: "Sacrílega". Então, as mulheres e as crianças gritavam novamente, dizendo: 'Ó Deus, uma sentença injusta aconteceu nessa cidade!' Após a procissão, Trifena a levou novamente sob custódia, porque Falconília, sua filha, em sonho lhe disse: 'Mãe, receba Tecla, essa estranha e eremita, em meu lugar para que ela interceda em meu favor para que eu seja transferida para o lugar dos justos'. Alexandre, em parte movido pela paixão a Tecla e em parte por sentir-se envergonhado pelo que aconteceu, a levou diante do governador. Quando ela confessou ter feito tais coisas, o governador a condenou às feras selvagens. As mulheres ficaram estupefatas, e gritaram do lado de fora do Tribunal: 'Julgamento mau! Julgamento ímpio!' Tecla pediu ao governador que permanecesse pura até que enfrentasse as feras selvagens (Atos de Paulo e Tecla 27-28; DE WEG, 1996, 27-34).

Alexandre julga-a a partir do seu status sócio-político - o primeiro de Antioquia -, e de sua coroa sacerdotal, um indício de que era um sacerdote do culto imperial, que eram sempre membros da elite local (BREMMER, 1996, p. 50-51). A desonra que Tecla lhe infringiu significa é tanto um insulto à sua pessoa quanto uma ofensa ao símbolo imperial e um desafio à autoridade imperial de Antioquia. Tecla, contudo, foi mais uma vez salva das feras selvagens pela intervenção divina, e o governador, esmagado pelo poder de Deus, liberta "a piedosa Tecla, serva de Deus" (RHEE, 2005, p. 172): 
Quando o governador ouviu isto, mandou trazer algumas roupas. Ele disse: 'Coloque estas roupas'. Tecla disse: 'Aquele que me vestiu quando estava nua entre as feras, me revestirá de salvação no dia do Juízo'. E tendo recebido as vestes, vestiu-se. O governador emitiu, imediatamente, um edito, dizendo: 'Tecla, a temente serva de Deus, eu a liberto para vocês'. E todas as mulheres gritaram bem alto e, em uníssono, louvaram a Deus, dizendo: 'Há apenas um Deus, $O$ que salvou a Tecla!' $E$ as bases da cidade se estremeceram com as suas vozes (Atos de Paulo e Tecla 38).

A mensagem anunciada pelo apóstolo também envolve o ascetismo, provocando tanto a ruptura do casamento e costumes sociais quanto perseguição à mulher convertida pelo seu marido que, em geral, detinha o poder político (proconsul, prefeito, rei), sustentava o culto tradicional, os valores da família e a ordem social. O conflito doméstico e social torna-se um conflito político, pois o apóstolo nega e opõe-se à autoridade política do marido e à pressão judicial exercida. Os detentores do poder encareceram, maltratam e executam os apóstolos, os quais sustentam a verdade cristã, desafiam a própria coerção e força política com seu poder carismático e o seu martírio (RHEE, 2005, p. 173).

Em Atos de Paulo, a pregação de Paulo e a denúncia dos ídolos e imagens pagãs em Éfeso provoca o tumulto dos ferreiros. Paulo, condenado às bestas pelo proconsul Jerônimo, na prisão converte ao seu evangelho encrático Artemila, mulher de Jerônimo, e Eubula, mulher de Diofantes, liberto de Jerônimo. Jerônimo, ao ouvir que "as mulheres sentavam dia e noite com Paulo" procura a execução de Paulo ao acelerar o dia da luta e ordenar um "leão perigoso". Ele estava furioso e acompanhado de uma multidão, que gritava: "Fora com o feiticeiro", mas o animal que devia atacar a Paulo era o leão que anteriormente Paulo batizara (ADARNIK, 1996, p. 60-74). Caiu, então, uma grande tempestade, Jerônimo ficou ferido, e Paulo e o leão foram libertados:

[...] o leão olhou para Paulo e Paulo para o leão. Paulo reconheceu que aquele era o leão que ele havia batizado. E movido pela fé, disse: "Você é o leão que batizei?" O leão respondeu: "Sim". Paulo the disse novamente: "Como você foi capturado?" O leão respondeu: "Da mesma forma que aconteceu com você". Jerônimo enviou muitas feras para matar a Paulo e arqueiros contra o leão para matá-lo, mas uma grande e violenta tempestade caiu sobre a terra, embora o céu estivesse claro, de modo que muitos morreram [...] Mas a tempestade não atingiu a Paulo ou o leão, embora as outras feras tenham morrido pela tempestade sobremaneira grande, de modo que a orelha de Jerônimo foi ferida e arrancada, e o povo clamava na medida em que fugia: "Salve-nos, ó Deus, salve-nos, ó Deus, do homem que luta 
com as feras". E Paulo despediu-se do leão [...] saíram do estádio, foram para o porto e embarcaram num navio que partia para a Macedônia, pois havia muitos que embarcavam quando a cidade perecia. Paulo embarcou também como um dos fugitivos e o leão, como era seu costume, fugiu para as montanhas (SCHNEEMELCHER, 1992, p. 252).

Este milagre demonstra o poder do Deus cristão e indica a vitória de Paulo sobre Jerônimo e o julgamento de Deus sobre as autoridades terrenas. Ele neutraliza e humilha o reino terrestre, isto é, o Império Romano, e antecipa o cumprimento da advertência anterior de Paulo a Artemila e Eubula de que o mundo seria destruído por causa da impiedade dos homens. Jerônimo é o ímpio que se rebela contra o governo soberano de Deus e a sua cura subsequente destaca sua absoluta impotência diante do poder de Deus (RHEE, 2005, p. 173-174; SCHNEEMELCHER, 1992, p. 251254).

Atos de André apresenta o conflito entre Egeates, o proconsul da Acaia, e André, por causa de Maximila, que é apenas parte de uma luta de poder maior entre eles. Maximila converte-se ao evangelho encrático anunciado por André: "Já sei, Maximila, minha filha, que estás disposta por ti mesma a resistir contra tudo o que promete a união carnal, desejando apartar-te de uma vida repugnante e imunda" (Atos de André 37). Sua conversão provoca uma série de derrotas para Egeates. Ele perde o amor conjugal de Maximila, a piedade de Estratocles e a autoridade legal sobre eles, sua casa e todo o povo de Patras. Todos se tornaram leais a André, cujo poder e autoridade parecem ser maiores do que o poder militar de Egeates. O exercício da força bruta da parte de Egeates aumenta a simpatia e reverência das pessoas para com André, cuja atitude para com a morte na cena de martírio também revela desprezo para com a autoridade transitória do Império:

Mas já que Egeates se aproxima de mim, calo-me e ocupo-me dos meus filhos. O que devo dizer-Ihe antes de partir, dir-lhe-ei. Por que vens outra vez contra nós, Egeates? Por que te aproximas de nós, tu que nos és estranho? O que desejas desta vez? O que estás maquinando? Que vieste buscar? Que vieste dizer-me? Aproximas para libertar-me como se estivesses arrependido? [...] Soltarás aquele que já fugiu? Soltarás aquele que já está livre? Soltarás aquele que foi reconhecido pelo que é de sua natureza, ao que conseguiu sua misericórdia, ao que é amado por ele, ao que é para ti alheio e estrangeiro, ao que somente tens visto em aparência? Possuo aquele com quem estarei para sempre. Possuo aquele com quem viverei incontáveis séculos. [...] Que não te dê medo este homem terrível, nem possa crer que te domina, pois és meu. É teu inimigo; é um destruidor, falsário, corruptor, 
caluniador, não solidário, maníaco, intrometido, assassino, indolente, adulador, impostor, violento, iracundo, insensível; toda essa pompa material é seu adorno [...] Senhor, não permitas que André, que já está amarrado sobre o teu madeiro, seja libertado. Jesus, não me entregues ao diabo sem vergonha, eu que estou em cima do teu mistério. Pai, que o teu adversário não me solte, quando já estou pendurado sobre tua graça. Que o inferior não volte a humilhar ao que conheceu a tua grandeza (Atos de André 62-63).

A morte não é a derrota final, mas o triunfo final; é o meio de alcançar a perfeição da vida futura. A crucificação de André mostra seu desprezo para com o poder terreno de Egeates. No discurso na cruz, ele pronuncia o julgamento profético de Egeates e prevê a sua queda. O suicídio de Egeates após o martírio de André intensifica a derrota do poder terreno, simbolizando a vitória definitiva cristã sobre o poder político dos reinos terrestres (RHEE, 2005, p. 174-175).

Este mesmo tipo de enfrentamento do poder está também presente no martírio de Pedro [Atos de Pedro 30-41]. O prefeito Agripa, o principal antagonista de Pedro, e Albino, amigo do imperador, planejaram executar a Pedro porque as quatro concubinas de Agripa e a esposa de Albino ouviram a mensagem encrática do apóstolo e, "arrependendo-se, não quiseram mais coabitar-se com Agripa e Albino":

As quatro concubinas do prefeito, Agripina, Nicaria, Eufemia e Doris, reuniam-se também com Pedro. Ao escutar sua pregação e todas as palavras do Senhor, sentiram-se comovidas em suas almas e concordaram em permanecer puras e afastadas do leito de Agripa. Por essa razão, começaram a ser incomodadas por ele [...] Certa mulher, formosíssima, esposa de Albino, amigo de César, de nome Xantipa, havia se afastado de Albino e frequentava a casa de Pedro junto com outras mulheres. Este, enlouquecido pelo amor de Xantipa e admirado de que sem sequer se deitara no mesmo leito, enfureceu-se como uma fera e queria destruir a Pedro, pois sabia que ele era a causa da separação conjugal (Atos de Pedro 33-34).

Agripa, então, ordena a crucificação de Pedro, acusando-o de "ateísmo":

Enquanto Pedro pronunciava estas palavras e todos os irmãos derramavam lágrimas, quatro soldados se apoderaram dele e o levaram diante de Agripa. 


\begin{abstract}
Este, movido por sua paixão doentia ordenou que ele fosse crucificado, acusando-o de ateísmo. Todos os irmãos, ricos e pobres, órfãos e viúvas, humildes e poderosos, correram para ver e tirar a Pedro dali. O povo gritava sem descanso e com uma só voz dizia: 'Que delito Pedro cometeu? Que mal ele fez?' (Atos de Pedro 36).
\end{abstract}

Pedro, seguindo as orientações do Senhor, aceita de bom grado crucificação, e chama a Agripa de servo de Satanás. Na descrição do martírio de Pedro fica assinalada a vitória sobre Agripa, que também foi reprendido por Nero por ter matado a Pedro sem o seu conhecimento: "Nero ficou sabendo posteriormente que Pedro havia morrido, e repreendeu ao prefeito Agripa que o condenara sem o seu consentimento, pois desejava castigá-lo de forma mais completa e demorada" (Atos de Pedro 41).

Atos de Tomé apresenta também a oposição de Misdeus e de seu parente Carisius a Tomé. As esposas de Misdeus e Carisius abraçam o ensino de abstinência dos apóstolos, e a rivalidade erótica torna-se uma luta política entre o marido alienado e o apóstolo sedutor, que acaba por provocar a morte do apóstolo. O contraste entre o poder terreno militar inferior e a derrota e o poder espiritual superior celestial e a vitória são inequívocas. A esposa de Misdeus, filho, nora, capitão e toda a multidão tornam-se leais e obedientes ao apóstolo estrangeiro e não mais ao rei. Embora encarcerado, Tomé não está confinado pela autoridade terrestre. Quando interrogado por Misdeus, fala sobre quem de fato domina. Para Tomé, o próprio rei está sob o senhorio universal de Jesus Cristo: "Meu Senhor Jesus é mais poderoso do que todos os poderes, reis e governantes" (119). Como no caso do martírio dos outros apóstolos, os eventos que envolvem seu martírio, paradoxalmente, acentuam a vitória do poder celestial. Por ocasião do seu martírio, Tomé ora a Cristo e, depois de sua morte, aparece ao seu inimigo, que tinha outro filho que precisava ser liberto dos demônios. Depois que seu filho teve a saúde restaurada através do poder que emanava do lugar onde estavam os ossos do apóstolo, Misdeus converte-se (169-170). A dependência desesperada do rei dos restos mortais de Tomé e sua subsequente conversão indicam a vitória definitiva de Cristo e do seu apóstolo. De fato, isto prova que o rei está à mercê da misericórdia de Jesus Cristo. O Senhor Jesus demonstra compaixão, poder e julgamento sobre o rei terreno, cuja fidelidade é agora transferida para o rei celestial (RHEE, 2005, p. 175).

\title{
O patronato social e a política do império
}

O patronato, a principal forma de relações de poder no Império Romano, permeava todas as esferas da sociedade mediterrânea. Neste sistema, o patrono, que tinha status superior e poder, oferecia benefícios aos clientes, como suporte material, proteção e influência e prestígio sócio- 
político. As pessoas privadas de direitos civis da sociedade romana tinham acesso à esfera politica somente através da ligação com um patrono; o cliente devia demonstrar gratidão na forma de lealdade, honras, elogios ou outros favores que o patrão exigisse. Dessa forma, a proteção e apoio eram importantes para as associações e indivíduos. Além disso, estas relações eram basicamente assimétricas, sendo que este sistema operava em múltiplos estratos sócio-políticos, era um meio importante de legitimar a ordem social e reforçar a ordem e hierarquia existentes (DE WEG, 1996, p. 18; SALLER, 1982, p. 7-39). O culto imperial, em particular, capitalizou o sistema de patronato ao propagar a resposta na forma de culto e homenagem ao imperador, considerado como o maior patrono e benfeitor do império².

Atos de Pedro desafia a rede de patronato social a partir de uma perspectiva cristã e desafia o sistema social e político existente. Apresenta a Cristo como o patrono de todos os crentes, superior aos patronos humanos, incluindo o imperador. $\mathrm{O}$ apóstata Marcelo, mais tarde restaurado, passa a doar aos cristãos e não mais ao imperador, até ao ponto em que Nero reclama de que está privado de recursos com presumível patrono:

Irmão Pedro, cremos que entre os homens ninguém foi tão sábio quanto Marcelo. Todas as viúvas que esperavam em Cristo nele encontravam refúgio. Todos os órfãos dele recebiam alimento. O que mais, irmão? Todos os indigentes invocavam a Marcelo como protetor, e sua casa era chamada morada dos pobres e forasteiros. O imperador lhe disse: 'Mantenho-te afastado de todo encargo para que não espolies as províncias para entregálas aos cristãos'. Marcelo Ihe respondeu: 'Todos os meus bens são teus'. César Ihe respondeu: 'Seriam meus se tu os conservasses para mim. Mas na realidade não são meus, porque os dás a quem queres, em especial a pessoas de baixo nível (Atos de Pedro 8).

\footnotetext{
${ }^{2} \mathrm{O}$ culto imperial, baseado na "ideologia imperial de poder", tornou-se central para esta unidade desde a época do governo de Augustus (29 a. C.-14 d. C.). Como uma das manifestações da teologia imperial que fundamentava ideológica e religiosamente o Estado romano, o culto imperial não era um fenômeno homogêneo, mas uma síntese carregada de tensão entre a ideologia do culto helenístico ao soberano e as concepções romanas das personalidades extraordinárias favorecida pelos deuses. Ele constituía um laço de unidade do império e símbolo da fidelidade ao imperador e ao Estado da parte de todas as pessoas, envolvia um conjunto de ritos religiosos e sua função principal era a legitimação política da honra do imperador e da sua família. O culto imperial era o laço de unidade do império, símbolo da fidelidade de todos os cidadãos ao imperador e ao Estado. Nele, o decisivo era seu caráter de religião e lealdade, e a não participação nos atos rituais, que celebravam e confirmavam a sua incolumidade, levantava a suspeita de deslealdade política fundamental. Nesse sentido, ao delimitar o que é "culto imperial" devemos ter cuidado para não encobrirmos as distinções que os antigos faziam da relação entre religião e política. Não havia um termo grego ou latino no período anterior ao cristianismo para religião ou política no sentido em que utilizamos esta palavra. Religio significava reverência, consciência e diligência para com os superiores, não exclusivamente os deuses. A palavra era também usada coletivamente, como designação dos ritos e cerimônias do culto divino e de tudo o que está ligado a ele (res divinae oposta a res humanae). A religio pré-cristã não estava preocupada com virtudes pessoais e interiores, como crença, mas com comportamento e atitude exterior, ou seja, com a observância e não com a fé, com a ação e não com o sentimento. Isto, naturalmente, não quer dizer que os pagãos não experimentavam emoções durante os seus cultos, mas que este aspecto não era central ao conceito e significado de religio. O significado da palavra religião no sentido moderno como um sistema que envolve ação, rituais e filosofia, teologia, dogmas, cosmologia e mitologia foi desenvolvido especificamente no âmbito da religio Christiana. Cf. WENGST, Klaus. Pax Romana. Pretensão e Realidade. Experiências e percepções da paz em Jesus e no cristianismo primitivo. São Paulo: Edições Paulinas, 1991, p. 70-76; GRADEL, Ittai. Emperor Worship and Roman Religion. Oxford: Clarendon Press, 2002, p. 4.
} 
Da mesma forma, Eubola, o senador ressuscitado e sua mãe viúva, a rica e adúltera matrona Crise tornam-se patronos ao oferecer suas dádivas à comunidade cristã:

Eubula, de sua parte, depois que recuperou os seus bens, colocou-os a serviço dos pobres, e creu no Nosso Senhor Jesus Cristo. Reconfortada, desprezando e renunciando a este mundo, ajudava a viúvas e órfãos e vestia aos pobres" [...] O jovem que fora ressuscitado dizia: 'Não me afastarei de Pedro'. Sua mãe, por sua parte, foi alegre e cheia de gozo para sua casa. No dia seguinte ao sábado, foi a casa de Marcelo levando a Pedro duas mil moedas de ouro, e lhe disse: 'Reparte estas moedas às virgens que sevem a Cristo'. O jovem que fora ressuscitado dentre os mortos, ao ver que não havia feito nenhuma doação, foi à sua casa, abriu um armário e ofereceu a Pedro quatro mil moedas de ouro, dizendo: 'Eu, que ressuscitei, apresento uma oferta dupla e, desde hoje, me entrego a Deus como vítima dotada de palavra" [Atos de Pedro 17]. [...] "Chegado o domingo, Pedro pregava aos irmãos e os exortava a perseverar na fé em Cristo. Estavam presentes muitos senadores e cavalheiros, e senhores ricas que se fortaleciam na fé. Havia também ali uma mulher muito rica chamada Crise - porque todos os utensílios de sua casa eram de ouro e porque desde sua infância jamais havia utilizado vasilha de prata ou cristal, mas somente dourada - que disse a Pedro: 'Pedro, servo de Deus, vi em meus sonhos ao meu lado aquele que chamas teu Deus, que me dizia: 'Crise, entrega ao meu servo Pedro dez mil moedas de ouro [...] Eu as trouxe, pois, temendo sofrer algum dano de quem me apareceu e voltou ao céu'. Após pronunciar estas palavras, depositou as moedas e se foi. Ao vê-lo, Pedro louvou ao senhor, porque os aflitos poderiam ser aliviados. Mas alguns dos presentes lhe disseram: 'Pedro, não fazes mal em receber dinheiro desta mulher? Fala-se mal dela em toda a cidade de Roma por causa da sua prostituição e porque não tem apenas um marido. Inclusive, ela se une com os seus próprios servos. Não participes da sua mesa, mas devolve-lhe o que dela vem'. Pedro, ao ouvi-los, sorriu e disse aos irmãos: 'Certamente desconheço que outro tipo de vida ela tem, mas sei, sim, que não recebi este dinheiro em vão. Ela, de fato o ofereceu como devedora de Cristo e o entrega para os seus servidores. O próprio Cristo se preocupa com eles" (Atos de Pedro 30).

As dádivas de todas estas pessoas são redirecionadas a Cristo, enquanto os patronos humanos são deixados de lado. Além disso, Atos de Pedro não apresenta nenhuma pessoa rica e poderosa como paradigma de fé. Parece que até mesmo que o maior patrono do império está em 
bancarrota e sem poder. Cristo é o patrono único e superior, e o "caráter universal e não mediado de suas dádivas", através dos milagres e do poder do apóstolo, transcende e enfraquece o patronato imperial (STOOPS, 1986, p. 91-100).

A limitação do poder e culto imperial ocorrem também na cena em que a estátua de mármore de César foi quebrada por um demônio que Pedro exorcizou. O culto imperial era parte integral da realidade social, política e cultural do Império Romano, sendo que numerosas estátuas imperiais representavam a imagem visível da presença onipotente do imperador. O governo e a piedade não estavam separados, nem tampouco os líderes destas atividades compunham grupos distintos. Os oficiais do culto imperial e os candidatos às funções governamentais eram das famílias ricas e proeminentes. De forma entusiástica, estas famílias apoiavam e ajudavam a expandir o culto imperial. Elas conduziam os sacrifícios, subscreviam festivais e construíam templos como parte de uma diversidade de deveres cívicos. Estas famílias também mobilizavam as massas em apoio ao imperador e reforçavam sua própria posição neste processo. No texto mencionado, o senador e dono da estátua Marcelo fica assustado com a quebra da estátua César e a punição que poderia advir:

Quando terminou de falar, Pedro abraçou a Marcelo. Ele se voltou logo para a multidão que o rodeava e viu entre ela um indivíduo que ria, no qual morava um demônio malvadíssimo. Pedro lhe disse: 'Mostra-se claramente diante de todos os presentes o que riu, quem quer que seja'. Diante destas palavras, um jovem entrou impetuosamente no pátio da casa, e atirando-se contra a parede, disse em voz alta: 'Pedro, há uma grande discussão entre Simão e o cachorro que Ihe enviaste. Um diz ao outro: 'Diga que não estou em casa'. [...] Pedro continuou: 'Tu, demônio, quem quer que sejas, em nome de Nosso Senhor Jesus Cristo, sai deste jovem sem absolutamente causar-Ihe mal, e manifesta-te aos presentes'. Depois de ouvir estas palavras o demônio saiu do jovem, apanhou uma grande estátua de mármore que estava no átrio da casa e a quebrou, com seus pés. Era uma imagem de César. Ao vê-lo, Marcelo golpeou a si mesmo e disse a Pedro: 'Uma grande falta foi cometida. Se isso chegar ao conhecimento de César através de alguns curiosos ele nos castigará com grandes penas'. Pedro respondeu: 'Há pouco tempo declaravas estar disposto a gastar toda a sua fortuna para salvar a tua alma. Mas se tu estás verdadeiramente arrependido e crês de todo o coração em Cristo, toma esta água corrente, suplica ao Senhor e borrifa-a em seu nome nos restos da estátua, que retornará à sua integridade anterior. Marcelo não duvidou nem um instante, mas creu do todo o coração. [...] Portanto, eu tomo a água em minhas mãos e em seu nome a borrifo sobre estas pedras, para 
que a estátua retorne à sua integridade anterior. A água caiu sobre os fragmentos e a estátua ficou intacta como antes (Atos de Pedro 11).

Pedro, então, diz a Marcelo que se ele cresse em Cristo sinceramente, a estátua seria restaurada, sendo necessário apenas borrifá-la com água. Marcelo confessa a Cristo, derrama água nos pedaços de "pedra" e a estátua retoma sua forma original, salvando-o do dano. Esta cena "esvazia o poder constituído do culto imperial, revelando a natureza real estátua imperial como meras pedras" (PERKINS, 1994, p. 298; PRICE, 1984, p. 191-206, 238-244). Além disso, o exorcismo foi realizado mediante a aspersão de água, então o relato da recomposição da estátua de César pode ser visto como purificação de um ídolo, pois a imagem imperial foi tomada pelo próprio demônio expulso do corpo do jovem (PEREA YÉBENES, 2008, p. 176).

A denúncia do imperador e do império está também presente no relato do martírio de Pedro, que apresenta Nero de forma totalmente negativa. Nero é veículo de tentação para Marcelo, o governador da província, que ajudava os cristãos pobres e os forasteiros. Tentado pelo imperador, Marcelo rechaça os cristãos, transformando a virtude em blasfêmia, por obra do diabo. O diabo manifesta-se, talvez, como alter ego do próprio imperador ou como personificação do pagão que ostenta o poder: "Tu endureceste o coração de Herodes, inflamaste o Faraó e o obrigaste a lutar contra Moisés, o santo servo de Deus. Tu deste a Caifás a audácia para entregar Nosso Senhor Jesus Cristo a uma multidão iníqua, e, até ao presente momento, atiras dardos envenenados às almas inocentes" (Atos de Pedro 8). Nero foi objeto da ira cristã porque na sua figura coincidem vários atos infelizes para sua memória: acusador e perseguidor dos cristãos, causador da morte de Pedro na época do seu governo e responsável pelo encarceramento e decapitação de Paulo. Disso decorre que na literatura popular e piedosa, como Atos de Pedro, ele é apresentado como um inimigo a combater, como um demônio (PEREA YÉBENES, 2008, p. 179-181). Nero também revela sua natureza "ímpia e má" depois do martírio de Pedro. Ele ficou irado porque sua intenção era punir severamente a Pedro por causa da sua atividade missionária entre os seus servos. Ele "procurou destruir os irmãos que Pedro tinha instruído", mas o apóstolo lhe apareceu numa visão e disse-Ihe: "Nero, não podes perseguir ou destruir os servos de Cristo. Não ponhas neles as tuas mãos" (41). Nesta visão o imperador é punido servilmente por um pregador cristão, o que acaba sendo "uma inversão da realidade dos mártires cristãos que na época eram torturados e mortos nos festivais imperiais". Nero, então, "fica com medo e afasta-se dos discípulos desde aquele momento" (41), sendo "decisivamente removido como ameaça para a comunidade cristã" (PERKINS, 1994, p. 298). O apóstolo realiza o que era impensável segundo os padrões convencionais: confronta a César, triunfa sobre ele e limita o seu poder diante de Deus.

A oposição radical entre o cristianismo e o império romano culmina no martírio de Paulo, que é descrito por meio da linguagem apocalíptica sobre o reinado universal de Cristo (BOLYKI, 1996, p. 92-107). Pátroclo, copeiro do imperador que ressuscitara, confessa diante de Nero que Jesus Cristo é o "rei das eras" e "destruirá todos os reinos da terra", sendo o único que permanecerá "por toda a 
eternidade”: “'Pátroclo, estás vivo?' Ele disse: ‘Estou vivo, César'. Então ele disse: ‘Quem te fez viver?' O jovem, nascido pela conviç̧ão da fé, disse: 'Cristo Jesus, o rei das eras'. César, perplexo, disse: 'Ele é o rei das eras e destruirá todos os reinos?' Pátroclo respondeu: 'Sim, ele destruirá todos os reinos da terra, é o único que permanecerá para sempre, e nenhum reino escapará dele"'. Com três outros "homens principais de Nero", ele promete ser fiel e lutar como soldado de Cristo: "Nós também pertencemos ao exército do rei das eras":

Mas certo Pátroclo, copeiro do imperador, veio mais tarde e, incapaz de ir até Paulo por causa da grande multidão, sentou numa alta janela e o ouvia quando ele ensinava a palavra de Deus. Mas já que o ímpio diabo tinha inveja do amor dos irmãos, Pátroclo caiu da janela e morreu, e estas novas foram rapidamente levadas a Nero. Mas Paulo, percebendo no Espírito disse: "Irmãos, ao diabo foi dada uma oportunidade para tentá-los. Saiam e vocês encontrarão um jovem caído do alto e morto. Levantai-o e trazei-o a mim". Então eles saíram e o trouxeram. E quando a multidão o viu, eles ficaram perturbados. Paulo disse a eles: "Agora, irmãos, mostrem a vossa fé. Venham todos, supliquemos ao Senhor Jesus Cristo, que este jovem possa viver e não sejamos molestados". Mas quando eles suplicaram, o jovem respirou novamente e sentando-o num animal, enviaram-no de volta vivo junto com outros que eram da casa de César. Quando Nero ouviu sobre a morte de Pátroclo, ele ficou muito angustiado [...] Mas o seus servos disseram as novas, dizendo: "César, Pátroclo está vivo e está de pé diante da mesa". Quando César ouviu que Pátroclo estava vivo, ele temeu e não queria entrar. Mas quando entrou, ele viu Pátroclo e gritou: "Pátroclo, você está vivo!" E ele disse: "Eu estou vivo, César". Mas ele disse: "Quem te fez viver?" O jovem, nascido pela conviç̧ão da fé, disse: "Cristo Jesus, o rei das eras". César, perplexo, disse: "Ele é o rei das eras e destruirá todos os reinos?" Pátroclo respondeu: "Sim, ele destruirá todos os reinos da terra, é o único que permanecerá para sempre, e nenhum reino escapará dele". Mas ele o golpeou na faze e disse: "Pátroclo, você também serve ao rei dos exércitos?" E ele disse: "Sim, Senhor", pois ele me ressuscitou quando estava morto". E Barsabas, Justus, Orion, o Capadócio, e Festo, da Galícia, homens principais de Nero, disseram: "Nós também pertencemos ao exército do rei das eras". Mas ele os aprisionou, depois de torturar terrivelmente os homens que ele muito amava, e ordenou que os soldados do grande rei fossem procurados, e proclamou um decreto que dizia que todos os que fossem cristãos e soldados de Cristo deveriam morrer (Martírio de Paulo 1-2). 
Nero, então, persegue os cristãos, executando a muitos deles sem julgamento. Paulo, levado diante de Nero como líder, declara que há soldados de Cristo em toda e terra e prediz sua ressurreição. Ele se identifica com um "fiel soldado do Deus vivo e fala sobre a morte de fogo para aqueles que não adoram o Rei Eterno":

E entre as muitas pessoas, Paulo também foi trazido preso e todos os seus companheiros os saudaram, de modo que César viu que ele era o líder. Ele Ihe disse: "Homem do grande rei, agora meu prisioneiro, porque te parece bem vir secretamente ao império dos romanos e recrutar soldados em minha província". Mas Paulo, cheio do Espírito Santo, disse diante de todos: "César, não somente de tua província nós recrutamos soldados, mas de todo o mundo. Se esta acusação é feita contra nós, que não seja excluído ninguém que deseja servir ao meu rei. [...] pois nem ricos nem o esplendor da presente vida te salvará, mas se você se submeter e suplicar-lhe, então serás salvo. Pois ele destruirá o mundo com fogo de uma única vez". Quando César ouviu isso, ele ordenou que todos os prisioneiros fossem queimados e que, segundo a lei dos Romanos, Paulo fosse decapitado (Martírio de Paulo 3).

Paulo profetiza sua aparição a Nero após sua morte e é executado. Entretanto, no momento da sua execução, leite respinga na roupa do soldado e testemunhas glorificam a Deus, deixando Nero, filósofos e um centurião desorientados. Paulo, o "soldado de Deus", aparece a Nero e declara que ele será julgado por derramar "o sangue dos justos". Nero, então, liberta os prisioneiros, incluindo Pátroclo, com grande perplexidade e medo:

Então Paulo foi conduzido à presença dele [...] e ele tomou a decisão de que ele deveria ser decapitado. Paulo, então, disse: 'César, não viverei por pouco tempo para o meu rei. E se eu for decapitado, isto farei: Eu ressuscitarei e aparecerei a ti, pois não estou morto, mas vivo para o meu Senhor Jesus Cristo, que julgará o mundo'. Longus e Cestus disseram a Paulo, 'Quem é esse rei em quem você crê, sem mudar de opinião mesmo estando para morrer? Paulo respondeu e disse, 'Vocês são ignorantes [...] arrependam e serão salvos do fogo que virá sobre toda a terra. Pois nós lutamos, não como vocês pensam, por um rei terreno, mas celestial: ele é o Deus vivo que virá como juiz por causa das obras ímpias que acontecem neste mundo.' [...] Então Paulo, com sua face voltada para o Oriente, levantando os olhos para os céus, orou. Depois da oração [...] ele estendeu o pescoço sem falar mais 
nada. Mas quando o seu pescoço foi golpeado, respingou leite na roupa do soldado. E quando o viram, o soldado e todos os que ali estavam ficaram admirados e glorificavam a Deus, que concedeu esta graça a Paulo. Então eles vieram e contaram a César o que havia acontecido. [...] Então, Paulo apareceu por volta da nona hora, quando muitos filósofos e um centurião estavam com César. Diante de todos, Paulo disse: 'César, sou um soldado de Cristo. Não estou morto, mas vivo em meu Deus. Mas, para ti, homem infeliz, haverá grandes males e grande punição, porque derramaste injustamente o sangue dos justos' [...] Quando Nero ouviu isso ficou muito atemorizado e ordenou que os prisioneiros fossem libertados, incluindo Pátroclo e seus companheiros (Martírio de Paulo 4-6).

O sentimento subversivo e contrário ao império é claro nesta narrativa. Ela utiliza o termo "soldado" e suas palavras cognatas 14 vezes, e os termos "rei", "grande rei" e "rei eterno" 12 vezes (SCHNEEMELCHER, 1992, p. 260-263). As imagens apocalípticas do texto projetam uma inimizade política entre o Cristianismo e o reino terrestre, particularmente o Império Romano. Esta linguagem militar, junto com o conceito de destruição universal do mundo, seu caráter antirromano e as exigências ascéticas se assemelham à Nova Profecia apocalíptica, da mesma época do Martírio de Paulo. Os cristãos são os soldados leais de Cristo, não do imperador. Eles servem a Cristo, o rei eterno, que se opõe ao governante temporal. Não é possível harmonia com o império, pois os cristãos não podem servir a dois senhores. Trata-se, certamente, de um eco do mesmo sentimento do Apocalipse de João. Paulo, nos Atos Apócrifos, "desafia a autoridade do Estado", é "inimigo do imperador e uma pessoa que procura o martírio". A antítese entre a igreja e o império é definitiva (RHEE, 2005, p. 178-179).

Resumindo, há nos Atos Apócrifos dos Apóstolos uma unidade fundamental entre religião, política e ordem social. Estas narrativas refletem a realidade histórica da época em que foram produzidos ao indicar que a identidade cristã tornava a pessoa passível de morte. Além disso, o sua mensagem ascética rejeitava 0 ato sexual independentemente do status marital; no mundo do ascetismo, as retóricas de gênero, sexualidade e salvação estão combinadas num discurso que objetiva criar uma esfera alternativa da realidade [COOPER, 1996, p. 45-67; PERKINS, 1995, p. 2530], oposta a este presente mundo corrupto. Há também uma conexão entre renúncia sexual e liberdade humana e a implicação social que isso provoca. Estes Atos retratam a "superioridade do ethos e moralidade sexual cristã com exaltação da virgindade e continência sexual radical, por um lado, e a condenação do casamento e relação sexual, pelo outro". Nesse sentido, eles representam uma ameaça às normas sociais tradicionais e rompem a ordem estabelecida da sociedade grecoromana.

Os Atos Apócrifos dos Apóstolos apresentam também os cristãos como violadores da lei e como pessoas que se rebelam contra a ordem presente. Os conflitos entre os apóstolos e as 
autoridades políticas culminam na antítese entre Cristo e o imperador, e a influência e função do patronato humano é limitada à luz do patronato de Cristo. Os convertidos oferecem suas dádivas à comunidade cristã. Eles são redirecionados a Cristo, enquanto os patronos humanos são deixados de lado. Eles também confrontam o imperador, como em Atos de Pedro, que situa no cristianismo o poder superior e a autoridade que supera a personagem mais poderosa do mundo. As cenas apresentadas em geral esvaziam o poder constituído do culto imperial, demitizam o poder imperial e desafiam o próprio imperador. A luta dos apóstolos é uma luta entre o poder deste mundo e o poder do outro mundo. É inequívoco o contraste entre o poder terreno militar inferior e a derrota e o poder espiritual superior celestial e a vitória. A rejeição dos ideais culturais e sociais tradicionais em favor de novos ideais assinala a reformulação das pressuposições estabelecidas, sendo esta uma característica que definia a identidade cristã como representada nos Atos Apócrifos dos Apóstolos.

\section{Referências}

ADARNIK, T. The baptized lion in the Acts of Paul. In: BREMMER, J. N. (Ed.). The Apocryphal Acts of Paul and Tecla. Studies in the Apocryphal Acts of the Apostles 2. Kampen: Kok Pharos, 1996. p. 6074.

BAUCKHAM, Richard. Imaginative literature. In: ESLER P. (Ed.) The early christian world. London \& New York: Routledge, 2000. v. 2. p. 791-812.

BOLYKI, J. Events after the martyrdom: missionary transformation of an apocalyptic metaphor in the martyrium pauli. In: BREMMER, J. N. (Ed.). The apocryphal acts of Paul and Thecla. studies in the apocryphal acts of the apostles 2. Kampen: Kok Pharos, 1996. p. 92-106.

BREMMER, J. N. Magic, Martyrdom and Women's Liberation in the Acts of Paul and Thecla. In: BREMMER, J. N. (ed.). The apocryphal acts of Paul and Thecla. studies in the apocryphal acts of the apostles 2. Kampen: Kok Pharos, 1996. p. 37-59.

COOPER, Kate. The Virgin and the bride: idealized womanhood in late antiquity. Cambridge: Harvard University Press, 1996.

DE WEG, Magda Misset-van. A wealthy woman named Trypahena: patronesse of Thecla of iconium. In: BREMMER, J. N. (Ed.). The apocryphal acts of Paul and Thecla. studies in the apocryphal acts of the apostles 2. Kampen: Kok Pharos, 1996. p. 16-35.

ELLIOTT, J. K. The apocryphal new testament. Oxford: Oxford University Press, 1993. 
GRADEL, Ittai. Emperor worship and roman religion. Oxford: Clarendon Press, 2002.

PEREA YÉBENES, Sabino. Demonios, exorcismos y emperadores em los Hechos del Apóstol Pedro. Revista de Ciencias de las religiones, Madrid, n. 13, p. 167-181, 2008.

PERKINS, Judith. The social world of the acts of Peter. In: TATUM, J. (Ed.). The search for the ancient novel. Baltimore: Johns Hopkins University Press, 1994. p. 296-307.

PERKINS, Judith. The suffering self: pain and narrative representation in the early christian era. London \& New York: Routledge, 1995.

PIÑERO, Antonio y CERRO, Gonzalo del. Hechos Apócrifos de los Apostoles I. Madrid: Biblioteca de Autores Cristianos, 2012.

PRICE, S. R. F. Rituals of power: The Roman imperial cult in Asia Minor. Cambridge: Cambridge University Press, 1984.

RHEE, Helen. Early christian literature: Christ and culture in the second and third centuries. London: Routledge, 2005.

SALLER, Richard P. Personal patronage under the early empire. Cambridge: Cambridge University Press, 1982.

SCHNEEMELCHER, W. New testament apocrypha. Kentucky: Westminster John Knox Press, 1992. v. 2.

STOOPS, R. F. Patronage in the Acts of Peter. Semeia, v. 38, p. 91-100, 1986.

WENGST, Klaus. Pax romana, pretensão e realidade: experiências e percepções da paz em Jesus e no cristianismo primitivo. São Paulo: Edições Paulinas, 1991.

Recebido em 04.08.2015 - aprovado 25.09.2015 